\title{
Serpin A9
}

National Cancer Institute

\section{Source}

National Cancer Institute. Serpin A9. NCI Thesaurus. Code C106017.

Serpin A9 (417 aa, $\sim 47 \mathrm{kDa}$ ) is encoded by the human SERPINA9 gene. This protein is involved in trypsin activity regulation. 